\title{
Law Book Hunting in the Heartland: A Life in Books
}

\author{
M.H. Hoeflich ${ }^{*}$
}

Like many people, books have been a joy and a solace to me for much of my life. An unhappy and solitary childhood led me to libraries and bookstores from an early age. Throughout high school, I spent much of my spare time in the public library reading a vast array of novels and nonfiction books, often simply wandering up and down the stacks looking for something to catch my attention. I spent far less time in bookstores because books were expensive, and I had limited financial resources. During my senior year in high school, I managed to make periodic trips to Book Row, the stretch of secondhand bookstores on Fourth Avenue in Manhattan (New York City, not Kansas). ${ }^{1}$ I haunted one bookshop in particular, Dauber \& Pine-now long gone-because the basement was full of "specials," books so badly used or out of date that they were priced under one dollar. It was a dusty bibliophilic heaven.

At the age of seventeen I went off to Haverford College, a small Quaker liberal arts school on Philadelphia's Main Line. The four years I spent at Haverford transformed my life in a multitude of ways, both in the classroom and out. One of the most important ways, however, was in turning my interest in books generally into an obsession with antiquarian books. This came about through the intervention of one professor and two bookshops.

Richard Luman came to Haverford at the same time as I: the fall of $1969 .^{2}$ He came to Haverford from teaching at the University of Chicago Divinity School. ${ }^{3} \quad$ I first met him during orientation week when professors teaching freshman seminars met with prospective students. Richard was offering a seminar on the history of Iceland in the Middle

\footnotetext{
* John H. \& John M. Kane Distinguished Professor of Law, University of Kansas.

1. See generally Marvin Mondlin \& Roy MEAdor, Book Row: AN ANECDOTAL AND PiCTORIAL History OF THE ANTIQUARIAN BOOK TRADE (2003).

2. Richard Luman, OTTUMWA COURIER ONLINE (May 31, 2010), https://obituaries.ottumwa courier.com/obituary/richard-luman-770293191.

3. $I d$.
} 
Ages. To those who know me, this seminar would seem not to be one that would be of interest, since I am a New York Jew. But, my first encounter with Richard was in a large room where all the professors were gathered at separate tables to meet students and describe their seminars. When I walked up to Richard's table, there he sat, holding a large, very old book from which he was reciting Icelandic sagas in a very loud and dramatic voice. When I got closer and discovered that although he was reciting the sagas in English, the text from which he was reading was in Icelandic, I was sold. How could I not take a course from a scholar like this!

Richard was a true polymath, expert in everything from medieval history to the development of railroads in the United States. He was also a prodigious reader and collector of books. He was the kind of professor I have always tried to be. He frequently invited students to his house for dinner and discussions. He was a confirmed bachelor and his row house next to the campus was filled with thousands of books dating from the seventeenth century on. And Richard was happy to allow students to take the rare volumes off the shelves, examine them, and even borrow them with a promise that they would be read and returned. He was one of the two Haverford faculty members who shaped my later life as a reader, scholar, and book hunter. ${ }^{4}$

The two bookshops that became my favorite book hunting haunts were the Bryn Mawr alumnae used bookshop in Bryn Mawr and George Allen's bookshop on Chestnut Street in Philadelphia. ${ }^{5}$

The Bryn Mawr College Alumnae Association for many years operated a variety of used bookstores around the United States to raise money for the college. There was one just off campus in Bryn Mawr. Bryn Mawr and Haverford were, when I attended, single-sex colleges. Haverford was all male and Bryn Mawr was all female. The colleges were less than two miles apart and the path between the two was well trod by students seeking educational or social resources at the two colleges. When I first stepped into the used bookshop, I was entranced.

4. For more on Richard's impact on me, see the obituary of him that I published. Mike Hoeflich, Teachers Have Lasting Impact, LAWRENCE J.-WORLD (June 17, 2010, 12:00 AM), https://www2.ljworld.com/news/2010/jun/17/teachers-have-lasting-impact/ [https://perma.cc/6YGN -N9YT].

5. For a discussion of Mr. Allen and his bookshop, see Daniel Traister, Remarks at a Memorial Service, Held at Trinity Memorial Episcopal Church, 2212 Spruce Street, Philadelphia (Nov. 29, 1998), https://www.sas.upenn.edu/ traister/allen.html [https://perma.cc/2EPK-SUBG]. Mr. Allen also wrote a history of his book company. See George Allen, History of William H. Allen, BOOKSELLER, 1918-1997 (1977), https://www.sas.upenn.edu/ traister/george.html [https://perma .cc/X58X-CHTB] (last visited Mar. 26, 2020). 
Thousands of books lined shelves throughout the shop. But it was one set of books that caught my eye: the Handy Volume issue of the Encyclopcedia Britannica, a photographic reprint of the eleventh edition. ${ }^{6}$ Why was I so interested in this set of books? The answer is simple. In our seminar, Richard Luman would refer frequently to the eleventh edition of the Britannica as the best source for information on history, languages, and law. Indeed, many of the legal articles were written by the great English legal historian Frederic William Maitland. ${ }^{7}$ So when I saw the set for sale, I felt what has been called "book lust" for the first time. The price was thirty dollars, far more than I could afford. I left the shop dejected. I returned the next day and the next day and, finally, on the fourth day I withdrew almost a month's worth of living expense money from my bank account and returned to buy the set. I spent the month living on peanut butter and jelly sandwiches but happy, nonetheless. I still have the set.

George Allen's shop in Philadelphia became a monthly and sometimes weekly visit for me beginning in my sophomore year at Haverford. Mr. Allen presided over the narrow, two-story shop filled with books on Latin and Greek and all periods of history. Four-hundredyear-old volumes sat on the shelves next to newly published books. Although the prices seemed high to me at the time, I now realize that they were quite inexpensive. The books reflected Mr. Allen's remarkable life and interests. He was a Haverford graduate who had studied classical languages, a veteran of World War II who had been among the first to enter the infamous Führerbunker and had married an Indian princess. His store was a magical place and every trip to it revealed new treasures to my eyes and fueled my book lust. This was where I first realized that hunting books was something like an Arthurian quest for the Holy Grail, except instead of searching for the Grail, I was searching for a new treasure that would inspire my intellectual development. By the time I graduated, I had spent hundreds of hours and virtually every penny I had earned at various odd jobs in Mr. Allen's shop.

After graduation from Haverford, I was fortunate enough to attend Cambridge University on a Fulbright scholarship. Cambridge in 1973

6. See Eleventh Edition and Its Supplements, BRITANNICA, https://www.britannica.com/topic /Encyclopaedia-Britannica-English-language-reference-work/Eleventh-edition-and-its-supplements [https://perma.cc/ZF3B-EPAP] (last visited Mar. 26, 2020).

7. See Frederic W. Maitland, BRITANNICA, https://www.britannica.com/biography/Frederic -William-Maitland [https://perma.cc/E3XD-6FTQ] (last visited Mar. 26, 2020) (describing the unique characteristics of the eleventh edition, as published in 1910). 
was a "bookman's" paradise. There were at least a dozen used and rare bookshops in the town. I haunted them all. Again, I spent virtually every penny I owned on bookish treasures. And, again, I was immensely lucky. One of the very best bookshops in Cambridge was Deighton, Bell. As soon as I discovered it and its four floors of rare volumes, it became a daily stop. By this time, I had decided to become a legal historian specializing in medieval Roman law and Deighton, Bell had literally hundreds of antiquarian Roman law books. I became friendly with the rare book specialist, John Sibbald, a young Scotsman who seemed to know everything one could know about antiquarian books. It was he who showed me the top floor of the shop, closed to the general public. It was filled with the remains of the library of Andrew Fletcher of Saltoun, a Scots patriot and book collector. ${ }^{8}$ There were hundreds of volumes, many of which had not been seen by the public for centuries. John Sibbald permitted me to catalogue those books for the shop and, on occasion, let me purchase a volume or two at a reduced price. I have many wonderful memories of my years in Cambridge, but none more wonderful than those of the days I spent in my aerie at Deighton, Bell, going through the remnants of the Fletcher library. By the time I left Cambridge in 1976 to attend Yale Law School, I was as much addicted to rare book hunting as a drug addict is addicted to heroin.

In the years since I went to law school, practiced law, and became a law professor there has been one constant in my life: my addiction to rare books, especially rare law books. That addiction has outlasted houses, cars, and even spouses. And it has also become the basis for much of my work as a legal historian. Many of my scholarly books and articles resulted from finding a bookish treasure and becoming fascinated with its text and history. ${ }^{9}$ Even when I was in practice in New York, I still spent the little spare time I had haunting used bookshops. It was in New York that I first realized that a successful book hunter required two things: luck and a prepared mind. I am a great believer in serendipity. Serendipity is that mysterious phenomenon that seemingly randomly puts a person in the right place at the right time so as to permit him to discover something or someone that will be of importance to him. I have been blessed with serendipity when it comes to book hunting, something I have written about previously. ${ }^{10}$ As for having a prepared mind, I think

8. See, e.g., Andrew Fletcher, Political Works (John Robertson ed., 1997). For an account of Fletcher's life, see G.W.T. OMOND, FLETCHER OF SALTOUN (1897).

9. See, e.g., M. H. Hoeflich, Legal Publishing in Antebellum America (2010). Many of the law book catalogues cited therein were mine, found through book hunting.

10. See generally Michael H. Hoeflich, Serendipity in the Stacks, Fortuity in the Archives, 99 L. 
this requires two things. First, one must be open to discovery. Second, one must have a store of knowledge that will allow one to recognize the significance of a book or artifact when it is found by chance. Without luck and a prepared mind, book hunting can be a frustrating activity.

I can give an example of just how frustrating book hunting without the requisite knowledge can be in my own life. I spend far too much time every week scanning newspaper and online notices of nearby estate sales and auctions to see which might have books or paper ephemeraunbound or unpublished paper items such as letters, diaries, etc.--for sale. A number of years ago, an advertisement for an estate auction in Atchison, Kansas caught my eye since it stated that it had a large number of books, magazines, and paper ephemera for sale. So, on the appointed day I drove up to Atchison to attend the auction. There were, in fact, a number of books that interested me, most of which I bought. There was also a table piled high with comic books. I know virtually nothing about comic books except that early editions of Superman and other superheroes can be quite valuable. In spite of my lack of knowledge, I decided to take a quick look at the comics. As I was looking through the piled-up comic books, one caught my eye. The author was Hugo Gernsback, one of the pioneers of modern science fiction (another interest of mine). It wasn't really a comic book at all, but rather an early paperback edition of his first novel, Ralph $124 \mathrm{C} 41+.{ }^{11}$ Although I had no idea of the value, I decided to bid on it just because it would be a fun item to own. One other person there decided to bid on the volume. When the bidding reached fifty dollars I dropped out and the other bidder got the book at sixty dollars. Imagine my chagrin when I got home and looked up the value to discover that copies were selling on the Internet for over $\$ 5,000$. If you don't know values you can pay too much or, even worse, lose an item worth far more than you thought!

To move on to the specific focus of this essay, my law book hunting adventures in Kansas and Missouri, I should begin by saying I know a great deal more about law books than I do about comic books. Also, there are far fewer people interested in law books (this includes auctioneers) than there are in comic books, so the chances of getting a bargain are quite good. In an earlier article, I wrote about finding a copy of Justice David Mulford Valentine's diary, including the only known copy of a contemporary account of Abraham Lincoln's 1859 campaign

LIBR. J. 813 (2007).

11. Hugo GernsBack, RALPH 124C 41+ (1925). 
speech in Leavenworth, Kansas at an auction in Lone Jack, Missouri. ${ }^{12}$ At that same auction I also found and purchased a manuscript volume recording student moot court cases at Harvard Law School supervised by Justice and Professor Joseph Story, a volume dating to the mid-1830s ${ }^{13}$ which I purchased at an estate auction in Tonganoxie, Kansas. I have also written about my discovery and purchase of the only extant notary's record book from Douglas County during the territorial period in Kansas. ${ }^{14}$ But there have been a number of other discoveries during my more recent "treasure hunts" and it is these that I will discuss in this essay.

Let me begin this portion of the essay by saying a few things more about how I conduct these treasure hunts. Every week I look at the auctions listed on www.kansasauctions.net. This website lists auctions taking place in Kansas and Western Missouri. ${ }^{15}$ Normally, the auction listings give a description of the auction, a list of items to be sold, and photographs of representative items. Not every item to be sold is listed. Indeed, books and paper ephemera are often not listed, but the better auctioneers will do so. Usually, bidders are permitted to view the items to be sold several hours before the auction begins and, on occasion, the night before. If I see something that looks interesting, I always visit before the auction to leave me time to look at the item and, if possible, do some research on my mobile phone to get some idea of rarity and value. This is the minimum preparation I do for an auction that has interesting items. Occasionally, I will also call the auctioneer with questions before the auction if I need information about the specific book offered for sale.

Let me begin with the most recent of my finds. In late July 2019, I found an auction listing advertising an auction to be held in Liberty, Missouri. The auction was being conducted by an auctioneer I knew slightly, although I had not attended many of his auctions in the past. What excited me was a listing for a book, "Commentaries on English Law by William Blackstone of Kent." Immediately I knew that the auctioneer had made an error transcribing the title, assuming the phrase

12. See generally "Went at Night to Hear Hon. Abe Lincoln Make a Speech": Daniel Mulford Valentine's 1859 Diary, 29 KAN. HIST. 100 (M. H. Hoeflich \& Virgil W. Dean eds., 2006), https:// www.kshs.org/publicat/history/2006summer_hoeflich_dean.pdf [https://perma.cc/2Q8M-7QUG].

13. I donated Justice Valentine's diary to the Kansas State Historical Society and the moot court handbook to the Harvard Law School Library.

14. See M.H. Hoeflich, An Unknown 1859 Notaries' Ledger from Douglas County, Kansas, 66 U. KAN. L. REV. 673 (2018).

15. See KANSASAUCTIONS.NET, https://www.kansasauctions.net/ [https://perma.cc/ZRR9 -69JK] (last visited Mar. 26, 2020). 
"William Blackstone, Kent" meant William Blackstone of Kent, rather than William Blackstone, Knight. But it was the publication date of the volume that made my hands shake. The date given was 1771 . This was an immensely important piece of information because 1771-1772 is the publication date of the first American edition of Blackstone's Commentaries published in Philadelphia by Robert Bell, a former partner of Benjamin Franklin. ${ }^{16}$ This edition, published in four volumes, was published by subscription, i.e., those who wanted the book had to subscribe for it and send the publisher a down payment on the set before it was published. ${ }^{17}$ Bell offered the set by subscription because he was unsure how well it would sell. ${ }^{18}$ In fact, it turned out to be a bestseller for a law book. ${ }^{19}$ Although it sold over 1,500 copies, the volumes are quite rare today. ${ }^{20}$

The first thing I did after looking at the listing was call the auctioneer and ask whether he had the other three volumes that completed the set. He told me that he would look and call me back. Of course, he never called. When the day of the auction dawned, I was up especially early, eager to be on the road to Missouri and the auction. We arrived at least two hours early. I found the first volume, as pictured in the online listing, on a table next to several other volumes. I sought out the auctioneer who told me that he had been unable to find any other volumes. Then, I went to look at the book itself which was on a table with a number of other older volumes.

The volume was all that I had hoped. The front free endpaper bore the inscription "William Jefferson Jones 1828." The title page had the following ownership inscriptions. The first read "Isaac Zane, Marlboro Ironworks 1778." Isaac Zane was a prosperous Quaker merchant based in Frederick County, Virginia. ${ }^{21}$ He became a justice of the peace in 1772 and was elected to the Virginia House of Burgesses in 1773 and the

\footnotetext{
16. Wilfrid PREST \& Michael Widener, 250 Years of Blackstone's COMMENTARIES: AN EXHIBITION 10 (2015), https://digitalcommons.law.yale.edu/cgi/viewcontent.cgi?article=1002\& context=britlaw [https://perma.cc/Q8B6-A4QY].

17. Id.

18. See HoEflich, supra note 9, at 131-32.

19. Id. at 132 .

20. Id. A complete set is, at the time of writing this article, available from Law Book Exchange in New Jersey for $\$ 1,250$. See Commentaries on the Laws of England, by the Late Sir W Blackstone, LAW BOOK ExCH., https://www.lawbookexchange.com/pages/books/70405/sir-william-blackstone -chitty-joseph/commentaries-on-the-laws-of-england-by-the-late-sir-w-blackstone [https://perma.cc [5AJC-AJKF] (last visited Mar. 26, 2020).

21. See generally Roger W. Moss, Jr., Isaac Zane, Jr., "A Quaker for the Times," 77 VA. MAG. HIST. \& BIOGRAPHY 291 (1969).
} 
Virginia House of Delegates in $1778 .^{22}$ He was the proprietor of the Marlboro Iron Works, which produced munitions for the Continental Army during the Revolutionary War. ${ }^{23} \mathrm{He}$ was also one of the original subscribers to Bell's edition of Blackstone's Commentaries. ${ }^{24}$ Why would a lawyer purchase a reprint of an American law book? I believe the answer in the case of Isaac Zane is twofold. First, he was a justice of the peace, a position which did not require a law degree but did require a basic knowledge of the laws. Second, he was a supporter of the Revolution and a member of the Virginia House of Burgesses. A knowledge of the Common Law as provided by the most important summary of the subject then known would have been immensely valuable to a legislator involved in the process of establishing the new nation. Blackstone was not simply a law book in the new nation; it was a handbook of law and political theory. ${ }^{25}$

The second ownership inscription, that of William Jefferson Jones, intrigued me. A quick Google search revealed a great deal about this fascinating lawyer and judge. According to the Tarlton Law Library at the University of Texas Law School:

The long and multifaceted life of William Jefferson Jones began in Caroline County, Virginia on September 27, 1810. When he was fifteen years old he began working as the recorder of deeds in the Caroline County clerk's office, where his brother was clerk. He studied law, obtained his license in 1829, and set up a law practice in Loudoun County .... In Washington he obtained his license to practice before the U.S. Supreme Court. In Georgia he met Mirabeau B. Lamar, future president of the Republic of Texas, and worked briefly at Lamar's newspaper office. He then moved on to Alabama, where he founded the Mobile Morning Chronicle, which he ran from 1836-37.

In late 1837 Jones moved to Texas and managed Lamar's campaign for president. When Lamar was elected, he commissioned Jones to raise a battalion to protect the frontier. In 1839 Jones fought in the Cherokee War. He also served as editor of the Houston National Banner. He was married, and he and his wife eventually had eleven children.

In 1840 Jones became a Texas Supreme Court justice when he was appointed judge of the Second Judicial District, and served in that

22. Id. at 297-302.

23. See id. at 300 .

24. See Subscribers in Virginia to Blackstone's Commentaries on the Laws of England, Philadelphia, 1771-1772, 1 WM. \& MARY Q. 183, 185 (1921).

25. See generally BlaCKSTONE AND His COMMENTARIES: BIOGRAPHY, LAW, History (Wilfrid Prest ed., 2009) [hereinafter BLACKSTONE AND HIS COMMENTARIES]. 
position until 1845. He and his wife moved to Columbus, where he practiced law and raised cotton and cattle, and in 1852 they moved to his estate, Virginia Point, which he established as a town. Jones was instrumental in developing the Galveston, Houston and Henderson Railroad, which provided daily service to Virginia Point. ${ }^{26}$

It is clear why Jones purchased this copy of Bell's Blackstone in 1828: he was preparing for admission to the Virginia Bar which he achieved in 1829 .

Jones did more than simply put his name on the volume. He also copied a passage from Cicero onto the book's second front free endpaper along with an English translation:

Haec studia adolescentiam alunt, senectutem oblectant; secundas res ornant, adversis persugium \& solatium praebent; delectant domi, non impediunt foris; pernoctant nobiscum, peregrinantur, rusticantur.

These (literary) studies are the food of youth and the consolation of age: they adorn prosperity and are the comfort and refuge of adversity: they are pleasant at home and incumbranced abroad: they accompany us at night in our travels and in our rural retreat.

\section{W.J.J.}

From a collector's perspective, it is always good to have an inscription in an owner's hand. But, in this case, it is also valuable in helping to understand an early nineteenth century American law student's reaction to Blackstone. In essence, the inscription is a paean to the value of Blackstone's Commentaries. ${ }^{27}$ This is quite clear contemporary evidence at the "grassroots" level of how important Blackstone was to lawyers in the new American republic.

I sat quietly in my seat for the auction to start. For more than an hour, the auctioneer sold pots, cast iron banks, and the occasional piece of glassware. Finally, he decided to sell a few books. The first volume he put up for sale was a tattered sixteenth century folio volume in German about Lutheran theology. Nobody was willing to bid on it. Fearing that if it didn't sell, he wouldn't move on to the Blackstone volume, I raised my hand and bid $\$ 50$. With a look of relief, the auctioneer hammered the volume down to me at his only bid, my $\$ 50$.

\footnotetext{
26. Justices of Texas: 1836-1982: William Jefferson Jones (1810-1897), TARLTON LAW LIBRARY, https://tarltonapps.law.utexas.edu/justices/profile/view/60 [https://perma.cc/8AY5-R86U] (last visited on Mar. 26, 2020).

27. See Michael Hoeflich, American Blackstones, in BlaCKSTONE AND His COMMENTARIES, supra note 25 , at $171-84$.
} 
Next came a seventeenth century Latin volume on the occult. Once again, nobody bid. Once again, I bid $\$ 50$ and the book was mine.

Finally, the auctioneer put the Blackstone volume up for sale. I immediately bid $\$ 100$ in the hopes of scaring off any competitors. It almost worked. Unfortunately, a gentleman sitting behind me, leaned over to his neighbor and said (and I heard) that he wanted an old book to take home even if he couldn't read it. He bid \$125. I was fairly sure that he wouldn't go too far higher since he was dressed in overalls and work boots, not the normal outfit of a rare law book hunter. I bid $\$ 150$. He bid $\$ 175$. And so it went until he bid \$300. I was becoming exasperated, but bid $\$ 325$. I heard my competitor say "Oh, damn" but he made no further bids. And so it was mine. I let out a whoop of joy, picked up my book and paid the cashier for it. Did I make a financial killing? No. But I now owned a first edition, twice signed and annotated copy of volume one of Bell's Blackstone, a book that will sit on the shelf next to my bed until the day I die.

The summer before I bid on and purchased Bell's Blackstone I made another terrific discovery at another auction near Kansas City International Airport. I went to this auction because the auctioneer had advertised that he had a first edition of the pamphlet printing of Lincoln's Gettysburg Address. While this is not a terribly rare item (although it usually fetches at least $\$ 5,000$ for a good copy), I had served as a consultant to the Lincoln Legal Papers Project in the 1980s when I was a law professor at the University of Illinois and since then I have had a keen interest in Lincolniana. Because I expected the copy to go for thousands of dollars, I knew that I could not afford to buy it, so I contacted a rare book dealer and friend of mine, Greg Talbot, owner of Law Book Exchange, and asked whether he would be interested in having me bid on the item for him. He was interested. When I went to the auction, as I expected, the copy of the Gettysburg Address went for many thousands of dollars and even my book dealer friend was not interested. However, when I arrived at the auction, I discovered that there were a number of other volumes up for sale, including the first nine volumes of the Journals of the Continental Congress, published in Philadelphia from 1777 to 1784 and covering the period from 1774 until $1783 .^{28}$ It is a beautiful set of books and was rebound at some point by

28. See Journals of the Continental Congress, 1774-1783, 9 Vols, 1777-1784, LAW BooK EXCH., https://www.lawbookexchange.com/pages/books/68714/united-states-continental-congress /journals-of-the-continental-congress-1774-1783-9-vols-1777-1784 [https://perma.cc/T3W9-Q9SG] (last visited Mar. 26, 2020). 
one of the greatest English bookbinders, Sangorski \& Sutcliffe. ${ }^{29}$ Much more interesting, however, was the fact that the second volume was printed by Robert Aitken, a Philadelphia printer. ${ }^{30}$ According to the bibliographer Michael von der Linn, the manager of the rare books department at Law Book Exchange:

[The] set includes the rarest imprint of the series: the Robert Aitken printing of Volume II, which records the opening events of the American Revolution. (The complete text of the Declaration of Independence is printed on pp. 241-246.) According to Aitken's account, 532 copies were completed. In the fall of 1777 the British forced Congress to evacuate Philadelphia. Unable to transport many copies of the Journal, many were left behind and later destroyed by the British, which accounts for the scarcity of this volume today. ${ }^{31}$

There were four of us bidding for the volume. After what can only be described as a "spirited" contest among us, I won the volumes for a price in five figures! I wish that I could say that the volumes are on the shelf next to my volume of Bell's Blackstone, but five-figure prices are well out of the reach of a law professor's salary. But I did get to hold them and spend a few hours with them before I sent them off to the Law Book Exchange, where they are today and available to anyone with a passion for legal history and the financial resources to own such a treasure! ${ }^{32}$

Not all of my law book hunting discoveries have been of great legal historical value as Bell's Blackstone or the Journals of the Continental Congress. Some have had less historical importance when viewed on a national scale and, yet, are absolutely fascinating, offering a glimpse of what lawyers' lives were like in Kansas. I treasure these glimpses into the history of the Kansas Bar as much as I do more nationally important books.

Several years ago, at a local Douglas County auction I saw a large folio volume bound in marbled paper crammed with what looked to be various bits of newspaper. This immediately excited me because I thought that it could be a scrapbook and I love scrapbooks of all sort. It is easy to imagine my delight when I opened up the volume and found a piece of a lawyer's letterhead pasted to the inside of the front cover. The letterhead had once belonged to "A.M.F. Randolph, Attorney-at-law,

\footnotetext{
29. Id.

30. Id.

31. Id.

32. See id.
} 
Burlington, Coffey County, Kas." It was even dated by hand: "12 Sept. 1877."

When I got home after the auction, I decided to do some research and discover who Mr. Randolph was. I was quite shocked when I did. A.M.F. Randolph was far from being a typical nineteenth century Burlington, Kansas lawyer. He was born in Allegany County, New York and educated at the Alfred Academy, the same school attended by Solon Thacher, a prominent Lawrence attorney. ${ }^{33}$ He then attended Allegheny College and moved to Kentucky to become a schoolteacher and to read law. ${ }^{34}$ He joined the Forty-first Kentucky regiment and fought for The Union during the Civil War. ${ }^{35}$ In 1868 , he moved to Kansas, briefly settling in Lawrence, but then moving to Burlington. ${ }^{36}$ He served as County Attorney for Coffey County until 1874 when he was elected Attorney General. ${ }^{37}$ After a single term in that office, he was elected to the Kansas House. ${ }^{38}$ In 1879, he was appointed as the Reporter for the Kansas Supreme Court, a position he held for eighteen years. ${ }^{39} \mathrm{He}$ had serious literary interests, published a number of articles, and in 1893 published The Trial of Sir John Falstaff: Wherein the Fat Knight Is Permitted to Answer for Himself Concerning the Charges Laid Against Him; and to Attorney His Own Case. ${ }^{40}$

Having learned this biographical information about Randolph, I realized that Randolph's scrapbook would provide a window into the mind of one of Kansas's most fascinating lawyers of the nineteenth century. ${ }^{41}$

The scrapbook itself consists of newspaper clippings divided into thirteen categories: law, politics, history, biography, obituary,

33. See Asa Maxson Fitz “A.M.F." Randolph, FIND A GRAVE, https://www.findagrave.com /memorial/38426214/asa-maxson_fitz-randolph [https://perma.cc/XLZ2 -FQ6X] (last visited on Mar. 26, 2020) (discussing biographical details of Randolph); see also Solon Otis Thacher, KAN. HISTORICAL SOC'Y: KANSAPEDIA (June 2011), https://www.kshs.org/index.php?url=kansapedia /solon-otis-thacher/17094 (discussing biographical details of Solon Thatcher) [https://perma.cc /VP6M-SRQF].

34. See Asa Maxson Fitz “A.M.F.” Randolph, supra note 33.

35. Id.

36. Id.

37. Id.

38. Id.

39. Id.

40. See A.M.F. Randolph, The Trial of Sir John FalstafF Wherein the Fat Knight Is Permitted to ANSwer for Himself Concerning the Charges Laid Against Him; AND to ATTORNEY HIS OWN CASE (1893).

41. Over the years I have published articles about a number of these little-known Kansas lawyers. See, e.g., Brian Moline \& M.H. Hoeflich, Some Kansas Lawyer-Poets, 55 U. KAN. L. ReV. 971 (2007). 
miscellany, poetry, wit and humor, book notices, home interests, agriculture, theology, and science. These categories represent the interests of a legal "Renaissance Man." It is marked "Scrap Book 3" on the front free endpaper recto, which suggests strongly that there were other scrapbooks once in Randolph's possession. ${ }^{42}$ I was not surprised to find the poetry category because many nineteenth century poets not only read poetry, but wrote it, often publishing their work in local newspapers. ${ }^{43}$ The categories of theology and agriculture fit well within the typical interests of a nineteenth century Kansas lawyer, as did wit and humor. ${ }^{44}$ The presence of a category on science is interesting and the clippings therein show the extent of Randolph's interests.

The clippings in the law section cover a wide variety of topics. They range from cases on taxation to female suffrage, ${ }^{45}$ Granger laws, notable cases, civil procedure in California, the validity of Kansas bonds, legal poetry, and a wide selection of other legal topics. It seems fairly clear that these clippings were those that Randolph read and found of interest. I doubt that he put these into his scrapbook for work purposes. Indeed, I doubt that this scrapbook had a place in his office library. Rather, the stories contained in these clippings were of a type that a literary lawyer would find of general interest and might want to save simply to have them available as an aide memoire. ${ }^{46}$

The section on politics features clippings on all of the parties then contending for power, as well as a number of articles on inflation and women's suffrage, two subjects of great importance at the time. The short history section features articles about the archaeology of the ancient world, including Schliemann's discoveries and, not surprisingly, articles on the Civil War. The biography section has a number of articles on famous figures including Lincoln, Sumner, and Webster.

The section of obituaries is divided between articles about murders and obituaries of famous men ranging from Senator William G. Brownlow, historian John Lothrop Motley, the writer Hans Christian Andersen, Civil War hero Admiral Raphael Semmes, religious leader Brigham Young, and an assortment of others. The wide variety of

42. I have been unable to discover the whereabouts of these other volumes or whether they have survived until the present.

43. See generally Anthology of Nineteenth Century AmeriCAn Legal Poetry (Michael H. Hoeflich ed., 2018).

44. See, e.g., Moline \& Hoeflich, supra note 41, at 983-84.

45. This was an account of the U.S. Supreme Court decision in Minor v. Happersett, 88 U.S. 162 (1875).

46. Scrapbooking was a very popular hobby at the time Randolph compiled this notebook, rather like stamp or coin collecting. 
celebrities whose obituaries are included demonstrates the wide expanse of Randolph's interests. The miscellany is, indeed, just that, with articles on many subjects including women, food and drink, and history. The poetry section has poems from several newspapers and popular magazines, as does the section on wit and humor.

The volume's section on book notices is, in many ways, the most fascinating because it provides evidence of Randolph's reading and literary interests. The notices contained in this section show a crosssection of the popular authors of Randolph's day. The section begins with a long review of John William Draper's History of the Conflict Between Religion and Science. ${ }^{47}$ This is followed by a notice of the publication of the centennial edition of George Bancroft's magisterial History of the United States of America. ${ }^{48}$ Other reviews discuss books by Ralph Waldo Emerson, Charlotte Brontë, Thomas De Quincey, James T. Fields, Charles Sumner, John Quincy Adams, and a biography of Daniel Webster. Unfortunately, no trace remains of Randolph's actual library, so we do not know whether he owned or read the books whose reviews he included in the scrapbook, but the fact that he took the time to cut out these reviews from newspapers and paste them in his scrapbook suggests a level of interest that may well have lead him to read the works.

The section on home interests contains clippings on a variety of domestic subjects, all of which seem to have been published in a newspaper column titled Home Interests. ${ }^{49}$ The final pages of the scrapbook contain a section of "Added Miscellany."

The depth and breadth of Randolph's interests come through very clearly in his scrapbook. Today, Randolph is largely forgotten even though, in his day, he was a well-known member of the Kansas Bar who argued a case in the U.S. Supreme Court, ${ }^{50}$ held elective office, served as Kansas Attorney General and Reporter for the Kansas Supreme Court, and published articles and a Shakespearean book. In sum, his life was quite accomplished, and knowledge of his scrapbook not only adds to our knowledge of the man, but also provides further evidence of the fact that the Kansas Bar in the nineteenth century was distinguished by men of

\footnotetext{
47. John William Draper, History of the Conflict Between Religion and SCIENCE (1874).

48. George BANCroft, History of the United StATES of AMERICA, From the Discovery OF THE CONTINENT (1876).

49. Many of the clippings have the phrase "Home Interests" at the top. I have been unable to discover from what newspaper they were taken.

50. See Burlington v. Beasley, 94 U.S. 310 (1876).
} 
great legal and literary achievements. Randolph should clearly take his place next to other better-known Kansas lawyers of his period, such as Eugene Ware. ${ }^{51}$

The final "treasure" I have discovered in my law book hunting expeditions that I will discuss today is not a book at all, but rather a single sheet advertising the broadside. ${ }^{52}$ I found it at an estate sale in Pittsburg, Kansas a number of years ago. The broadside was printed by the Kansas City Book Company of Kansas City, Missouri. The front of the sheet contains text and the reverse contains a plat map of the city of Indianapolis in Custer County, Oklahoma, the lots for which were up for sale.

The front text is fascinating. According to the broadside's text, the Kansas City Book Company had "[o]btained control of about one hundred lots in the best part of the new town of Indianapolis." The text does not reveal how this had happened. Book companies during this period did not generally deal in real estate. In fact, when writing a history of law book publishing in the United States, I discovered a letter in which a lawyer in need of law books offered to trade land he owned for books. The book company declined his offer. ${ }^{53}$ In the broadside I purchased, a book company apparently had acquired land and decided to formulate a novel offer. They were willing to trade a lot in the new town of Indianapolis, Oklahoma for twenty-five dollars in used "law books, standard works, or rare books at market prices." They reserved the right "to determine whether or not the books... to trade us will make an equitable exchange." They asked those who wished to accept their offer "to state honestly the condition of bindings, the date of the edition, and the name of the author and number of volumes to each set." They also offered to sell the lots for cash, five dollars down and five dollars per month until fully paid.

In studying nineteenth century law books, libraries, and legal publishing I have never come across a broadside like this nor an offer by a law book company to trade land for used law books. One can only imagine that there may well have been one or more lawyers, tired of the rigors of law practice, who decided to trade in a portion of their law library and start afresh as a homesteader in Oklahoma Territory. It is a marvelous document and tells a little-known part of our legal history.

I hope that my enthusiasm for law book hunting in Kansas and

51. For an account of Eugene Ware's life, see Moline \& Hoeflich, supra note 41, at 971-78.

52. The broadside is on file with the author.

53. HoEfLICH, supra note 9 , at 99. 
surrounding states has come through in this essay and might inspire some readers to take up the chase. It is not that I seek competition for books and ephemera. Rather, as I approach my seventh decade and my life slows down accordingly - and my ability to drive to distant auctions reduced considerably (a decade ago I thought nothing of driving 200 miles each way to a promising auction) - I find myself attending fewer auctions and estate sales. Yet, I know that there remain many treasures to be found in our region. I hate the notion of such books and papers to sit unsold and unloved, or to find their final resting place in a dumpster in a rural Kansas or Missouri town. When this happens, the history of the legal profession and of our state and nation suffer irreparable loss. ${ }^{54}$ So, I urge all of you to go online to www.kansasauctions.net each week to find good auctions to explore, check local newspapers for estate sales, particularly of lawyers, and become law book treasure hunters. You will not be sorry for doing so.

54. I have discussed this problem in Michael H. Hoeflich, Why the History of Kansas Law Has Not Been Written, 26 KAN. Hist.: J. CENT. Plains 264 (2003). 